\title{
Study of the Effect of Certain Physicochemical Parameters on the Distribution of Toxic Planktonic Taxa in Two Oceanic Sites Mehdia and Moulay Bousselham, Rabat Sale Kenitra Region, Morocco
}

\author{
A. Hal Aberrhaman, L. A. Lrhorfi, B. Bouhaddioui, R. Bengueddour \\ Biology Department, Laboratory Biochemistry, Biotechnology, Health and Environment, Faculty of Science, \\ Ibn Tofail University, Kenitra, Morocco \\ Email: azza-20111@hotmail.fr, alrhorfi_com@yahoo.fr,dr_bouchra2010@yahoo.fr, rachidbengueddour@yahoo.fr
}

How to cite this paper: Aberrhaman, A.H., Lrhorfi, L.A., Bouhaddioui, B. and Bengueddour, R. (2020) Study of the Effect of Certain Physicochemical Parameters on the Distribution of Toxic Planktonic Taxa in Two Oceanic Sites Mehdia and Moulay Bousselham, Rabat Sale Kenitra Region, Morocco. Open Journal of Marine Science, 10, 32-39.

https://doi.org/10.4236/ojms.2020.101003

Received: December 10, 2019

Accepted: January 17, 2020

Published: January 20, 2020

Copyright $\odot 2020$ by author(s) and Scientific Research Publishing Inc. This work is licensed under the Creative Commons Attribution International License (CC BY 4.0).

http://creativecommons.org/licenses/by/4.0/

\section{cc) (i) Open Access}

\begin{abstract}
The diversity of phytoplankton communities in marine waters depends on the environmental, physical, chemical and biological factors in which they occur. The aim of our work is to determine the effect of certain physicochemical parameters on the proliferation of five planktonic taxa (1: Alexandrium 2: Dinophysis 3: Gymnodinum; 4: Pseudonitzschia; 5: Proocentrum) identified on the sites of Mehdia and Moulay Bousselham, Gharb of Moroccobetween 2017 and 2018. The results confirm the presence of these toxic taxa in both sites but with different densities. The ACP has allowed separating two distinct groups with coefficients of determination of more than $70 \%$. Indeed, the first group concerning the site of Mehdia, it is characterized by an abundance of the taxa of Gymnodium and Pseudoni, which prefers salt water and oxygenated, thus important phosphate and nitrate levels. Moreover, unlike the temperature factor. However, the second group concerning the Moulay Bousselham site is located on the positive side of the axis, essentially characterized by moderately high temperatures. These conditions are favorable for the Dinophysis, Alexandrum and Proocentrum taxa. This trend makes it possible to classify the Moulay Bousselham site as a risk zone. In light of these results, the authorities of all stakeholders in the sector must increase efforts to overcome this constraint.
\end{abstract}

\section{Keywords}

Diversity, Plankton, Physicochemical Parameters, ACP, Risk, Mehdia and Moulay Bousselham 


\section{Introduction}

Water quality is recommended by increasing its degree of trophy, known as eutrophication. Eutrophication is defined as "nutrient enrichment of waters that results in a series of symptomatic changes such as increased production of algae and macrophytes" [1]. However, the study of bio-indicator organisms, allows evaluating the ecological state of an aquatic environment. According to Blandin (1986) [2], a biological indicator (or bioindicator) is an organism or group of organisms that, by reference to biochemical, cytological, physiological, ethological, or ecological variables, makes it possible to characterize the state of an ecosystem.

Phytoplankton are all the cyanobacteria and microalgae (microscopic plants) present in surface water that can be carried away by water currents [3] [4]. The factors favoring a better microalgal production are the illumination, and the temperature whose optimum is $18^{\circ} \mathrm{C}$ to $24^{\circ} \mathrm{C}$ according to the species. The $\mathrm{pH}$ must be between 8.2 and 8.7, nitrogen and phosphorus and other elements. Phytoplankton occupied the place of the first link in the food chain [5]; it is the basis of ecosystems in marine environments [6]. The distribution, abundance, production and biodiversity of different species or groups of plankton are likely to be profoundly affected by climate change and the physical and chemical properties of the oceans [3]. Of the many species that make up phytoplankton, some produce toxins called phycotoxins. They belong mainly to the Dinophycea class [7].

In Morocco, there are 84 listed wetlands according to the 1997 Protected Areas Study. An ongoing study reports about 300 sites covering an area of 400,000 ha. Morocco's Gharb is rich in wetlands such as the Mehdia area and Moulay Bousselham, which are considered among the most populated areas by planktonic species.

The objective of this study is to compare the spatiotemporal evolution of certain toxic planktonic species between two wet sites Mehdia and Moulay Bousselham.

\section{Material and Methods}

\section{1) Description of the study site}

The samples were taken from two ocean sites, the Mehdia and Moulay Boussleham in the Rabat-Sale-Kenitra region. The geographic coordinates of Mehdia and Moulay Bousselham are respectively "Latitude: $34^{\circ} 16^{\prime} 04^{\prime \prime} \mathrm{N}$; Longitude: $006^{\circ} 39^{\prime} 46^{\prime \prime} \mathrm{W}^{\prime}$ and "Latitude: $34^{\circ} 52^{\prime} 42.96^{\prime \prime N}$; Longitude: $6^{\circ} 17^{\prime} 35.99^{\prime \prime} \mathrm{W}$ ". The first site is a picturesque coastal town near the Kenitra city, $30 \mathrm{~km}$ northeast of the capital Rabat. The average annual temperature is $18.6^{\circ} \mathrm{C}$ and the average rainfall is $283 \mathrm{~mm}$. The second site is known for heavy rainfall in winter than in summer. The average annual temperature is $18.1^{\circ} \mathrm{C}$, and the average annual precipitation is $622 \mathrm{~mm}$.

\section{2) Identification of species}

For the identification of phytoplankton, a volume of $500 \mathrm{ml}$ of seawater is col- 
lected at $0.5 \mathrm{~m}$ depth using opaque glass bottles. The sample is then fixed with $2.5 \mathrm{ml}$ of alkaline lugol and placed in a cool box protected from light. In the laboratory, samples are recorded and stored in the dark at $4^{\circ} \mathrm{C}$. After vigorous stirring, the samples are decanted for 24 hours at room temperature. Then subjected to observation under optical microscope morpho-anatomic characters (shape, size and color) representing the identification keys retained by Graneli et al., 1990; Bourrelly, 1985 and Marcaillou-Le Baut et al., 1990 [8] [9] [10]. The cells are then counted per liter per vat.

\section{3) Statistical analyzes}

The collected data are entered on an Excel support, the exploitation is carried out on a statistical processing software. The analyzes selected in this sense are significance tests such as single-point analysis of variance, correlations, principal component analysis. The results are generally expressed as relative frequencies and/or means \pm standard deviation.

\section{Results and Discussion}

\section{1) Study of the density variation in the two sampling sites}

Table 1 summarizes the results of the descriptive analysis of the density of planktonic taxa identified in the two sampling sites. An Asterix marks significant differences. It appears from this table that:

Table 1. Characteristics of the taxa identified in the two sampling sites.

\begin{tabular}{|c|c|c|c|c|c|c|c|c|}
\hline \multirow[t]{2}{*}{ taxon } & \multirow[t]{2}{*}{ Site } & \multirow[t]{2}{*}{ average } & \multirow[t]{2}{*}{ Er. Std } & \multicolumn{2}{|c|}{$\begin{array}{l}95 \% \text { confidence } \\
\text { interval for the average }\end{array}$} & \multirow[t]{2}{*}{ Min } & \multirow[t]{2}{*}{$\operatorname{Max}$} & \multirow[t]{2}{*}{ student } \\
\hline & & & & lower & higher & & & \\
\hline \multirow{3}{*}{1} & Site 1 & 61.39 & 16.051 & 28.10 & 94.68 & 0 & 290 & \multirow{3}{*}{$\begin{array}{c}3.680 \\
(\mathrm{p}<0.049)^{*}\end{array}$} \\
\hline & Site 2 & 251.57 & 97.829 & 48.68 & 454.45 & 0 & 1990 & \\
\hline & Total & 156.48 & 51.023 & 53.71 & 259.24 & 0 & 1990 & \\
\hline \multirow{3}{*}{2} & Site 1 & 80.43 & 55.055 & -33.74 & 194.61 & 0 & 1250 & \multirow{3}{*}{$\begin{array}{c}3.51 \\
(\mathrm{p}<0.0435)^{*}\end{array}$} \\
\hline & Site 2 & 689.57 & 320.656 & 24.57 & 1354.57 & 0 & 7500 & \\
\hline & Total & 385.00 & 167.141 & 48.36 & 721.64 & 0 & 7500 & \\
\hline \multirow{3}{*}{3} & Site 1 & 532.61 & 249.478 & 15.22 & 1049.99 & 0 & 4500 & \multirow{3}{*}{$\begin{array}{c}0.62 \\
(\mathrm{p}<0.41)\end{array}$} \\
\hline & Site 2 & 326.09 & 82.684 & 154.61 & 497.56 & 0 & 1600 & \\
\hline & Total & 429.35 & 130.852 & 165.80 & 692.90 & 0 & 4500 & \\
\hline \multirow{3}{*}{4} & Site 1 & 3691.3 & 1112.20 & 1384.74 & 5997.87 & 0 & 19,000 & \multirow{3}{*}{$\begin{array}{c}1.28 \\
(\mathrm{p}<0.26)\end{array}$} \\
\hline & Site 2 & 7097.8 & 2799.29 & 1292.44 & $12,903.22$ & 0 & 65,000 & \\
\hline & Total & 5394.5 & 1510.73 & 2351.78 & 8437.35 & 0 & 65,000 & \\
\hline \multirow{3}{*}{5} & Site 1 & 4652.1 & 1444.09 & 1657.30 & 7647.04 & 0 & 28,000 & \multirow{3}{*}{$\begin{array}{c}0.17 \\
(\mathrm{p}<0.68)\end{array}$} \\
\hline & Site 2 & 4000.0 & 631.830 & 2689.66 & 5310.34 & 0 & 16,000 & \\
\hline & Total & 4326.0 & 780.842 & 2753.39 & 5898.78 & 0 & 28,000 & \\
\hline
\end{tabular}

1: Alexandrium. 2: Dinophysis. 3: Gymnodinum; 4: Pseudo-Nitzschia; 5: Proocentrum; Avg: average; ErStd: standard error; Min: minimum; Max: maximum; *: significant difference. Site 1: mehdia. Site 2: Moulay Bousselham. 
- For the Alexandrium taxon, the student test shows a significant difference between the mean density of the Mehdia site (mean $=61.39 \pm 16.05$ cells/liter) and the average density of the Moulay Bousselham site (mean $=251.57 \pm$ 97.83 cells/liter), with a $t$ value of 3.68 and a $\mathrm{p}<0.049$. Both sites displayed maximum densities of 290 cells/liter for the Mehdia site and 1990 cells/liter for the Moulay Bousselham site.

- The same for the Dinophysis taxon. The student test shows a significant difference between the two sites $(\mathrm{t}=3.51, \mathrm{p}<0.0435)$. The average density in the Moulay Bousselaham site greatly exceeds that of Mehdia, they are respectively 689.57 cells/liter and 80.43 cells/liter, with a maximum density of up to 7500 cells/liter.

- For the other three taxa, the student test did not show a significant difference between the two sites. However, differences in average densities are thus recorded. For the Pseudonitzschia taxon, the average density in the Moulay Bousselham site greatly exceeds that of Mehdia. In addition, the Gymnodinum and Proocentrum taxa were very abundant in the Mehdia site with average densities of 532.61 cells/liter and 4652.1 cells/liter, respectively.

The planktonic species identified all have toxic potency but to varying degrees. Because of this, the abundance of these species in the Moulay Bousselham site makes the environment really too incriminated.

\section{2) Study of the variation of physicochemical parameters in the two sites}

The results concerning the distribution of certain physicochemical parameters at the two sampling sites are given in Table 2. This table shows two groups of

Table 2. Physicochemical characteristics in the two sampling sites.

\begin{tabular}{|c|c|c|c|c|c|c|c|c|}
\hline \multirow[t]{2}{*}{ parameters } & \multirow[t]{2}{*}{ site } & \multirow[t]{2}{*}{ average } & \multirow[t]{2}{*}{ Er. Std } & \multicolumn{2}{|c|}{$\begin{array}{l}95 \% \text { confidence } \\
\text { interval for the average }\end{array}$} & \multirow[t]{2}{*}{ Mini } & \multirow[t]{2}{*}{ Maxi } & \multirow[t]{2}{*}{ student } \\
\hline & & & & lowe & higher & & & \\
\hline \multirow{3}{*}{ TC } & 1 & 19.174 & 0.51 & 18.12 & 20.23 & 15.00 & 24.0 & \multirow{3}{*}{$\begin{array}{c}0.05 \\
(\mathrm{p}<0.8)\end{array}$} \\
\hline & 2 & 19.326 & 0.47 & 18.34 & 20.31 & 15.50 & 24.0 & \\
\hline & Total & 19.250 & 0.34 & 18.56 & 19.94 & 15.00 & 24.0 & \\
\hline \multirow{3}{*}{ Salinité } & 1 & 34.430 & 0.30 & 33.80 & 35.06 & 32.00 & 38.0 & \multirow{3}{*}{$\begin{array}{c}1.12 \\
(\mathrm{p}<0.3)\end{array}$} \\
\hline & 2 & 34.796 & 0.16 & 34.46 & 35.14 & 33.00 & 36.0 & \\
\hline & Total & 34.613 & 0.17 & 34.26 & 34.96 & 32.00 & 38.0 & \\
\hline \multirow{3}{*}{$\mathrm{O}_{2}$} & 1 & 10.087 & 0.21 & 9.65 & 10.53 & 8.00 & 11.5 & \multirow{3}{*}{$\begin{array}{c}7.31 \\
(p<0.010)^{*}\end{array}$} \\
\hline & 2 & 9.413 & 0.13 & 9.14 & 9.68 & 8.20 & 10.5 & \\
\hline & Total & 9.750 & 0.13 & 9.48 & 10.02 & 8.00 & 11.5 & \\
\hline \multirow{3}{*}{ Nitrate } & 1 & 55.17 & 2.08 & 50.85 & 59.50 & 40.00 & 69 & \multirow{3}{*}{$\begin{array}{c}2.49 \\
(\mathrm{p}<0.12)\end{array}$} \\
\hline & 2 & 50.65 & 1.97 & 46.57 & 54.73 & 39.00 & 70 & \\
\hline & Total & 52.91 & 1.46 & 49.98 & 55.85 & 39.00 & 70 & \\
\hline \multirow{3}{*}{ Phosphate } & 1 & 2.217 & 0.14 & 1.93 & 2.51 & 1.50 & 3.8 & \multirow{3}{*}{$\begin{array}{c}3.98 \\
(\mathrm{p}<0.05)^{*}\end{array}$} \\
\hline & 2 & 1.830 & 0.14 & 1.55 & 2.11 & 0.80 & 3.0 & \\
\hline & Total & 2.024 & 0.10 & 1.82 & 2.23 & 0.80 & 3.8 & \\
\hline
\end{tabular}

ErStd: standard error; Min: minimum; Max: maximum; *: significant difference. Site 1: Mehdia. Site 2: Moulay Bousselham. 
parameters, the first group is composed of the parameters that have shown significant differences between the two sites, it is therefore represented by the dissolved oxygen parameters $(t=7.31, p<0.01)$ and phosphate $(t=3.98, p<0.05)$ and a second group consisting of temperature, salinity and nitrate parameters. In addition, the average oxygen and phosphate contents at the Mehdia site (mean oxygen $=10.09$, average phosphate $=2.22$ ) are higher than those recorded at the Moulay Bousselham site (mean oxygen $=9.41$, average phosphate $=1.83$ ). However, although the difference is not significant between the two sites, the average nitrate content in the Mehdia site (55.17) exceeds that of the Moulay Bousselham site (50.65). The temperature and salinity parameters show almost identical average values between the Mehdia and Moulay Bousselham sites, with contents close to $19.25^{\circ} \mathrm{C}$ and $34.6^{\circ} \mathrm{C}$ respectively.

The multiple pearson correlation test between the 5 physicochemical parameters studied by assembling the two sites shows that the temperature is moving in the opposite direction of nitrate $(r=-0.69)$ and phosphate $(r=-0.61)$. However, nitrate evolves in the same direction as phosphate $(r=0.59)$ (Figure 1).

- For the Mehdia site, we found negative correlations between temperature and phosphate parameter with a correlation coefficient of $(r=-0.78, p<0.000)$, between temperature and nitrate with a coefficient correlation of $(\mathrm{r}=-0.71$, $\mathrm{p}<0.000$ ), and between the temperature and the salinity parameter with a correlation coefficient of -0.42 and $p<0.046$. Similarly, there was a positive bond this time between oxygen and salinity $(r=0.50, p<0.016)$ on the one hand and between nitrate and phosphate on the other hand $(r=0.69, \mathrm{p}<$ 0.000 )

- For the Moulay Bousselham site, negative correlations were found between the temperature and the phosphate and nitrate parameters, with correlation coefficients of $\mathrm{r}=-0.47$, respectively; $\mathrm{p}<0.024$ and $\mathrm{r}=-0.69 ; \mathrm{p}<0.000$. Negative correlation thus binds salinity and oxygen $(\mathrm{r}=-0.52, \mathrm{p}<0.011)$ and a positive binding associates nitrate and phosphate $(\mathrm{r}=0.42, \mathrm{p}<0.049)$.

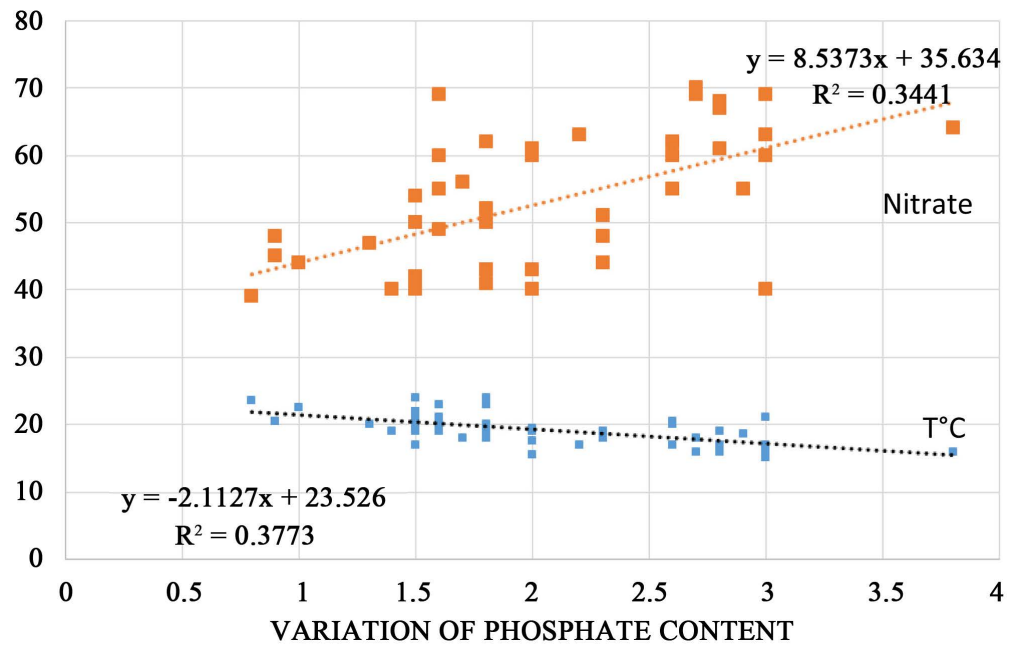

Figure 1. Projection of average nitrate points and temperature versus phosphate. 


\section{3) Joint analysis}

For the joint analysis of planktonic taxa and the physicochemical factors that they characterize, we used a principal component analysis ACP. The results are shown in Figure 2 and Figure 3. This graph shows two distinct groups.

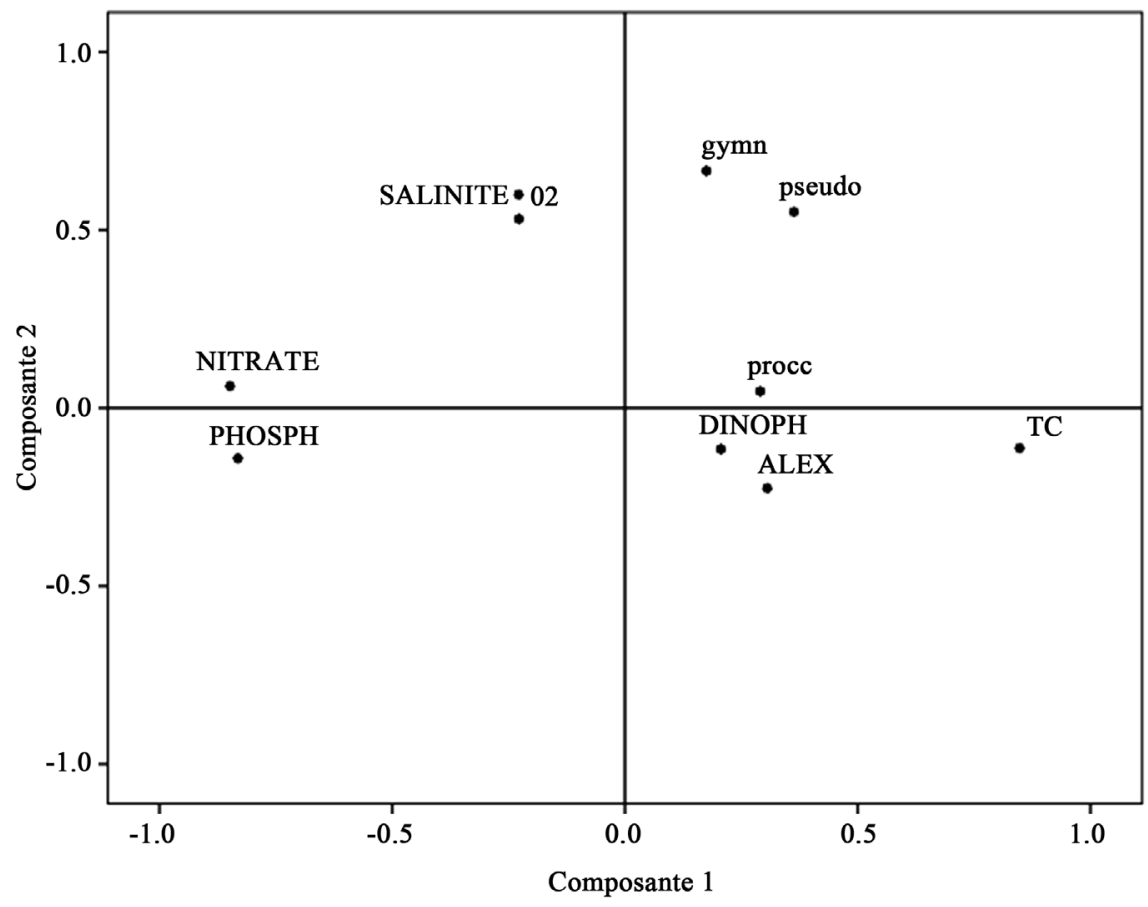

Figure 2. ACP projection of studied physicochemical parameters.

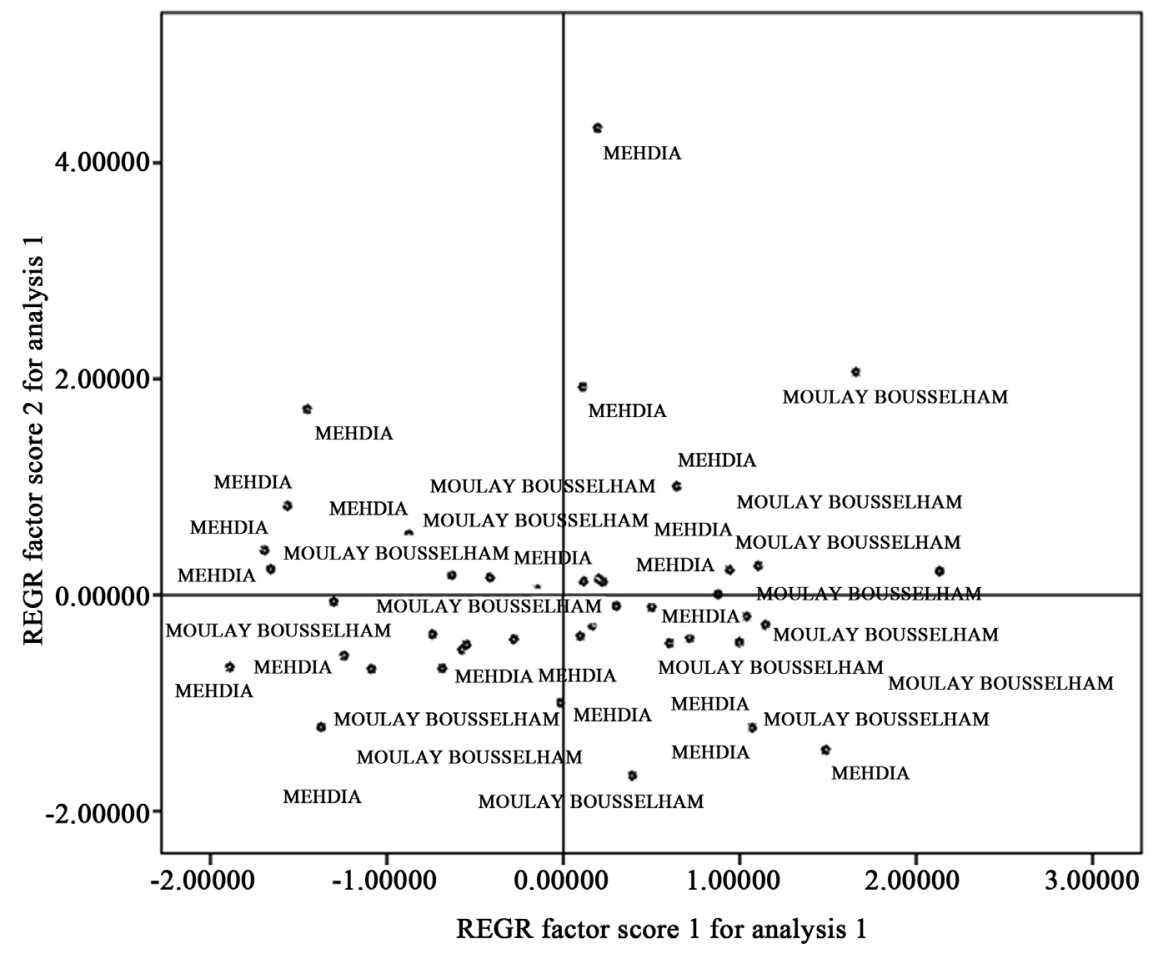

Figure 3. Projection of the coordinates of the two sampling sites. 
- The first group concerning the Mehdia site, it is characterized by an abundance of Gymnodinum and Pseudoni taxa that prefer saline and oxygenated waters, as well as important phosphate and nitrate levels and unlike the temperature factor.

- The second group concerning the Moulay Bousselham site is located on the positive side of the axis, essentially characterized by moderately high temperatures. These conditions are favorable for the taxon Dinophysis, Alexandrum and Proocentrum.

\section{Discussion}

The identification of the toxic species in the two Moroccan sites allowed us to mention five species known by their toxic power. Moreover, Dinophysis and Alexandrium are two planktonic taxa of which some species are capable of producing respectively diarrheal toxins and paralytic toxins. The abundance of these species is under the direct or indirect effect of several physicochemical parameters such as temperature, $\mathrm{O}_{2}, \mathrm{pH}$ etc. The effect of temperature on microalgal growth has been described by many authors, the latter confirming that the microalgae preference for temperatures between $15^{\circ} \mathrm{C}$ and $30^{\circ} \mathrm{C}$. Good oxygenation promotes a massive proliferation of phytoplankton and consequently the growth of these microalgae, provides an additional source of oxygen through its photosynthetic activity. Low oxygen concentrations indicate more active remineralization on the surface [11]. Indeed, when the temperature increases, the solubility of the gas decreases. The surface layer thus heated by solar radiation further limits the ocean/atmosphere oxygen exchanges and thus the surface layer is depleted. The observed decrease could also be due to a heterotrophic activity of remineralization of the organic matter in this zone [12].

\section{Conflicts of Interest}

The authors declare no conflicts of interest regarding the publication of this paper.

\section{References}

[1] OECD (1982) Eutrophication of Waters. Monitoring, Evaluation and Control Methods. Organization for Economic Co-Operation and Development, Paris, 164 p.

[2] Blandin, P. (1986) Bioindicators and Diagnosis of Ecological Systems. Ecology Bulletin, 17, 215-307.

[3] Bougis, P. (1974) Ecology of Marine Plankton II. Masson et Cie, Zooplankton, Paris, 191.

[4] Dufour, P. and Durand, J.R. (1982) Plant Production in the Ivory Coast Lagoons. Rev Hydrobiol Trop, 15, 209-230.

[5] Dhargalkar, V.K. and Ingoleb, S. (2004) Phytoplankton Identification Manual. National Institute of Oceanography, $2 \mathrm{p}$.

[6] Broutin, M., Caffier, G., Madi, M. and Artigas, L. (2011) Techniques for Monitoring the Abundance, Biomass and Diversity of Phytoplankton in Marine Waters. Ifre- 
mer, 2 .

[7] Sournia, A., Belin, C., Billard, C., Catherine, M., Erard-Le Denn, E., Fresnel, J., Lassus, P., Pastoureaud, A. and Soulard, R. (1992) The Repetitive and Expanding Occurrence of a Green Bloom-Forming Dinoflagellate (Dinophyceae) on the Coasts of France. Cryptogamie Algologie, 13, 1-13.

[8] Graneli, E., Sundstrom, B., Edler, L. and Anderson, D.M. (1990) Toxic Marine Phytoplankton. Elsevier, New York, 554.

[9] Bourrelly, P. (1985) Freshwater Algae. Introduction to Systematics. Volume III: Blue and Red Algae. The Euglenians, Peridinians and Cryptomonadines. Editions N. Boubée, Paris, 606 p.

[10] Marcaillou-Le Baut, C., Bardin, B., Bardouil, M., Bohec, M., Le Déan, L., Masselin, P. and Truquet P. (1990) Study of the Decontamination of Toxic Mussels (Diarrheal toxins) in the Laboratory and in the Wild. Internal Report, $21 \mathrm{p}$.

[11] Thingstad, T.-F., Li Zweifel, U. and Rassoulzadegan, F. (1998) P Limitation of Heterotrophic Bacteria and Phytoplankton in the Northwest Mediterranean. Limnology Oceanography, 43, 88-94. https://doi.org/10.4319/lo.1998.43.1.0088

[12] Diaz, F., Pouvesle, W. and Boudjellal, B. (1999) A Semi-Automatic, Wetoxidation Method for Simultaneous Determination of Particulate Carbon, Nitrogen, and Phosphorus Collected on Filters. Marine Ecology Progress Series, 180, 289-295.

https://doi.org/10.3354/meps180289 